\title{
Misdiagnosis of posterior sequestered lumbar disc herniation: report of three cases and review of the literature
}

\author{
Antonio Montalvo Afonso $\mathbb{~}^{1}$ - Olga Mateo Sierra ${ }^{1}$ - Oscar Lucas Gil de Sagredo del Corral ${ }^{1}$. \\ Antonio José Vargas López ${ }^{1}$ Lain Hermes González-Quarante ${ }^{1} \cdot$ Emma Sola Vendrell $^{2} \cdot$ Julia Romero Martínez $^{3}$
}

Received: 23 May 2018 / Revised: 17 June 2018 / Accepted: 17 June 2018

(C) International Spinal Cord Society 2018

\begin{abstract}
Introduction Posterior migration of sequestered disc is an extremely rare event that mimics more common spinal lesions as spinal tumors, making difficult its preoperative diagnosis and appropriate management. We retrospectively reviewed all lumbar disc herniations treated by surgery at our institution from 2006 to 2016 to identify cases with posterior sequestered disc fragments and possible misdiagnosis for other spinal lesions. Complementarily, a literature review of misdiagnosed cases of posterior migrated discs was undertaken.

Case report Three posterior sequestered lumbar disc cases (one intradural), were found among the 1153 reviewed surgeries. Two of them, presenting with progressive neurological deficit, were respectively misdiagnosed as pseudotumoral lesion and meningioma/neurogenic tumor on MRI. After intraoperative diagnosis and emergent resection, histology confirmed intervertebral disc tissue. The remaining case had an accurate preoperative diagnosis and after an initial conservative management finally underwent surgery because of refractory pain. Full recovery was achieved months after surgical treatment in all cases.

Discussion Non-tumoral lesions are the most frequent misdiagnosis of posterior sequestered lumbar disc described in the literature. Early surgical treatment is the standard management due to high incidence of cauda equine syndrome (CES); however, spontaneous regression of posterior sequestered lumbar disc herniations has been recently reported. In conclusion low incidence and similar clinical and radiological features with other more common posterior spinal lesions like hematomas, synovial cyst or abscess turns posterior sequestered disc herniations a diagnosis challenge. Despite high incidence of CES, an initial conservative management should be evaluated in selected patients without neurological deficit and wellcontrolled pain.
\end{abstract}

\section{Introduction}

Sequestered disc is defined as a displacement of disc material that breaks through the annulus fibrosus and the posterior longitudinal ligament and lose continuity with

$\triangle$ Antonio Montalvo Afonso

anmonta190@gmail.com

1 Department of Neurological Surgery, Hospital General Universitario Gregorio Marañón, 46 Dr. Esquerdo Street, 28007 Madrid, Spain

2 Department of Neuropathology, Hospital General Universitario Gregorio Marañón, 46 Dr. Esquerdo Street, 28007 Madrid, Spain

3 Department of Neuroradiology, Hospital General Universitario Gregorio Marañón, 46 Dr. Esquerdo Street, 28007 Madrid, Spain the disc of origin. Free fragments can migrate anywhere within the epidural space or even be located inside the dura mater. However anatomical barriers limit their migration, especially to the posterior epidural and/or intradural spaces where isolated disc fragments are exceptionally found. In the other hand, a wide variety of space-occupying spinal lesions located in the posterior epidural space share similar clinical course and radiological appearance to the unusual posteriorly sequestered discs making their diagnosis difficult and their management uncertain.

In this report, we present three cases of unusual posteriorly sequestered lumbar disc herniations and in addition we review the literature on misdiagnosed sequestered lumbar disc fragments.

A retrospective analysis was performed on patients undergoing surgery for lumbar disc herniations between 
2006 and 2016 at our department. Cases with atypical sequestered disc fragment migration on preoperative MRI were individually analyzed. Variables regarding age, sex, symptoms, neurological and radiological findings, disc level, initial and final diagnosis, treatment technique and outcome were reviewed and compared to previous literature on this entity.

\section{Case presentation}

A total of 1153 patients underwent lumbar disc herniation surgery. Three of them $(0.26 \%)$ showed atypical sequestered lumbar disc herniation at preoperative magnetic resonance imaging (MRI).

\section{Case 1}

A 45-year-old man with a four-week history of increasing low back pain following a heavy exercise with progressive bilateral leg weakness, more intense on his left side. At hospital admission he could not walk and complained of urinary incontinence. Physical examination revealed bilateral radiculopathy with positive straight-leg raising test sign, 3/5 strength on plantar flexion of both feet and hypoesthesia below both knees. Ankle jerks were hypoactive.

MRI demonstrated a left extradural posterolateral lesion, isointense on T1 and hyperintense on T2-weighted images, severely compressing the thecal sac at the L4-L5 level. After gadolinium injection, a rim enhancement appeared and suggested a pseudotumoral lesion.
An emergent L4-L5 bilateral laminectomy was performed. After removal of the ligamentum flavum a posterior epidural mass with fibroelastic consistency was identified. The lesion was removed and radicular decompression was achieved.

Histopathology was consistent with a degenerated intervertebral disc. The patient was completely relieved of his back pain and gradually recovered full strength.

\section{Case 2}

A 33 year-old male with a prior personal history of intermittent lumbagos caused by a L5-S1 listhesis, developed progressive back pain with radiating pain over his left leg for the last 5 months. He did not complain of leg weakness, bladder or bowel dysfunction.

On examination, he had a positive straight-leg raising test and no significant decline in muscle strength. Sensory exam and deep tendon reflexes were also preserved.

MRI revealed a hypointense T1 and hyperintense T2weighted images lesion at the left posterior epidural L4-L5 space suggestive of disc fragment. Furthermore, a spondylolytic spondilolisthesis at the same level was disclosed.

After a period of conservative treatment, patient finally underwent surgery. An L4-L5 microdiscectomy and transforaminal interbody fusion (TLIF) with L4-S1 pedicle screw fixation was performed. Below the ligamentum flavum, a sequestered posteriorly migrated disc fragment was observed and removed. Patient's back and leg pain improved progressively in the postoperative period.
Fig. 1 Case 1. Preoperative axial (a) T1-weighted MR image demonstrating an isointense left posterolateral epidural lesion showing rim enhancement (b) after gadolinium contrast.

Sagittal (c) and coronal (d) T2weghted images revealing completely occupation of spine canal at L4-L5 level by the hyperintense lesion
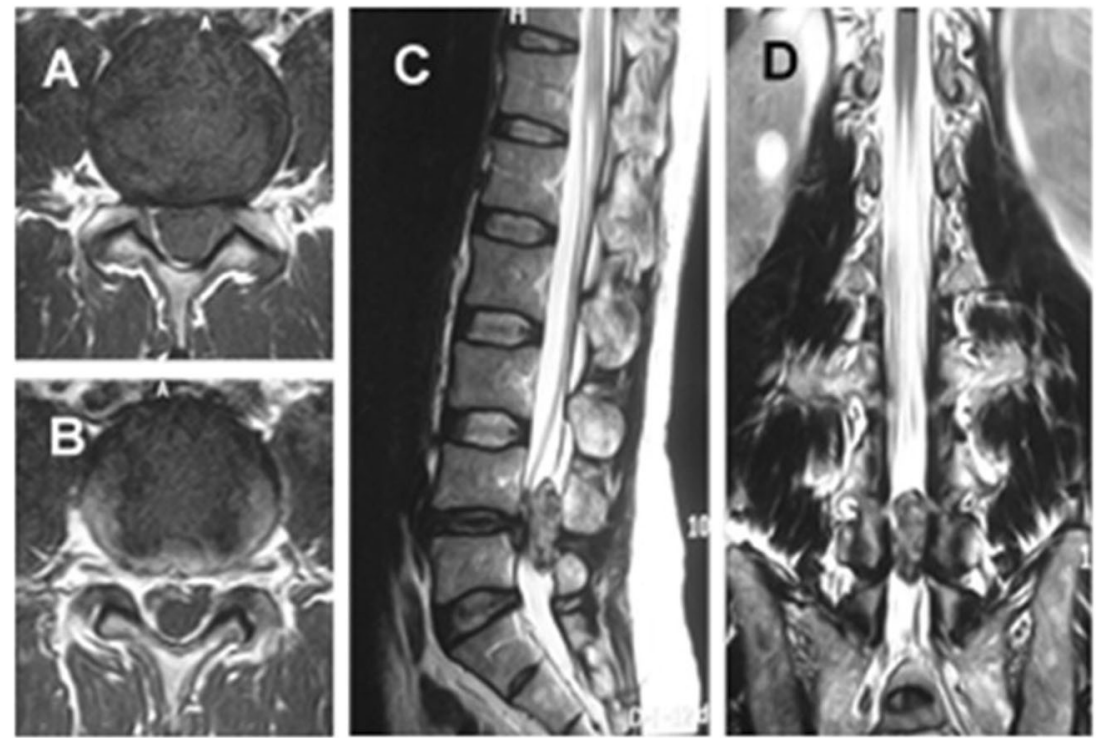


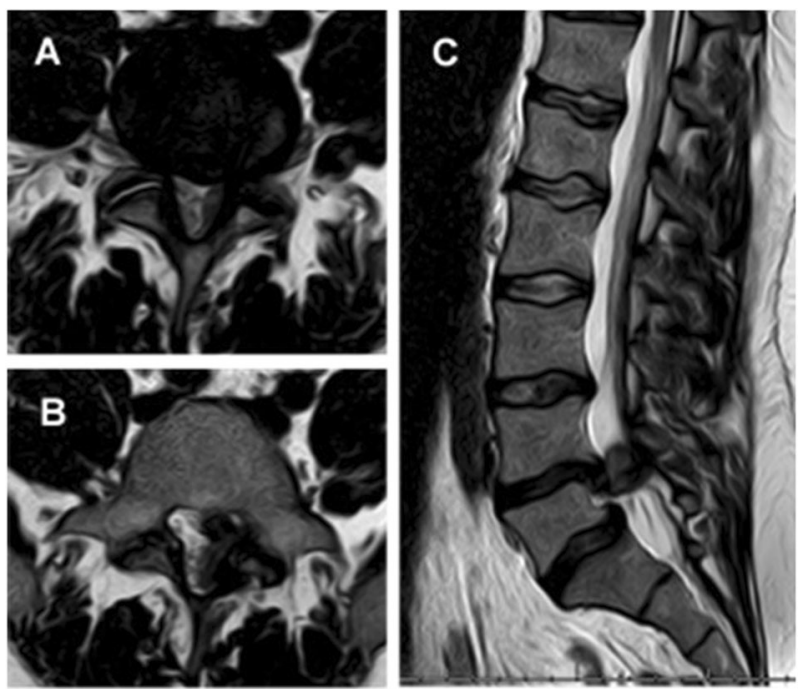

Fig. 2 Case 2. Axial T1-weighted (a) and T2-weighted (b) MR image showing a left posterolateral epidural disc fragment. Sagittal T2weighted image (c) showing sequestered disk fragment and a listhesis at L4-L5 level

\section{Case 3}

A 64 year-old male was admitted to the hospital with severe lumbar pain of acute onset, left sciatica, and progressive knee weakness for 3 months.

The physical examination revealed decreased sensation to light touch in the distal left lower extremity involving L5 dermatome. Strength in his lower extremities was preserved and deep tendon reflexes were decreased.

Electromyography evidenced acute denervation with chronic changes in left L5 root territory. MRI showed a large intradural lesion from midline to dorsal left radicular foramen at L3-L4 with no relation to disc space, suggesting a lumbar meningioma or other neurogenic tumor.

During surgery, a thinned dorsal duramater was observed (Figs. 1 and 2). After dural opening, a non-vascularized, strongly attached to duramater lesion was found, and enbloc resection was achieved. No anterior dural defect was identified. Histological examination revealed herniated disc tissue (Fig. 3e). Patient experienced almost full recovery over the following 6 months, with minimal distal sensitive lost.

\section{Discussion}

First cases of intradural and posterior migrated lumbar disc fragments were described by Lombardi in 1973 [1] and by Dandy in 1942 [2] respectively, when myelography was the gold standard for radiologic preoperative diagnosis. Since then, the advances in radiological methods like MRI with constant improvement in imaging techniques, and the
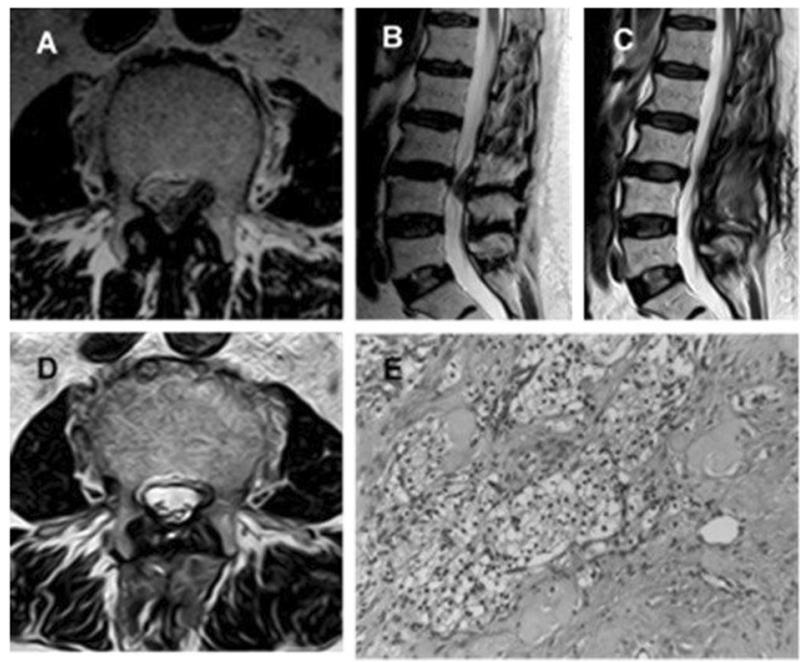

Fig. 3 Case 3. Preoperative axial (a) and sagittal (b) T2-weighted MR images showing a left postero lateral epidural lesion at L3-L4. Postoperative axial (c) and sagittal (d) T2-weighted MR images demonstrate complete resection of the lesion. Photomicrograph of this tissue specimen stained with hematoxylin-eosin at 20x magnification (e) showing cartilaginous tissue surrounded by fibrosis and lymphohystiocitary infiltrate

development in research through cases reported in the literature have tried to facilitate their diagnosis and treatment. However, nowadays it is still not uncommon a preoperative misdiagnosis of this entity.

\section{Epidemiology}

One of the most important reasons for unusual sequestered disk herniations misdiagnosis is their extremely rare incidence in clinical practice. Although sequestered disc fragments accounts for $28.6 \%$ of all disc herniations [3], migration to the posterior epidural space or into the dural sac is rare, with an incidence rate about $0.27-1.04 \%[4,5]$. The natural barriers, made up of nerve root, sagittal midline septum, lateral membrane, epidural fat tissue, venous plexus, lateral Hoffman's ligaments, hinder disc fragment migration to the posterior epidural space [6-9], and duramater to the intradural space [10].

\section{Etiopathogenesis}

The etiopathogenesis of these atypical herniations is still unclear. Age incidence, in the series of posteriorly sequestered disc, is reported to be older than the overall population with simple disc herniations [5, 11, 12], and regarding their anatomical disc origin, L3-L4 or L4-L5 are the most frequently affected intervertebral spaces [5, 12, 13]. It has been reported some risk factors like insufficiency of ligaments and other structures that attach fragments to the anterior epidural space and larger spinal canals with wide space 
Table 1 Summary of reported cases of posterior sequestered lumbar disc fragment misdiagnosis as spinal lesions

\begin{tabular}{|c|c|c|c|c|c|c|c|}
\hline Author [ref.] & Age/sex & Level & Symptoms & Preoperative diagnosis & T1WI & T2WI & $\mathrm{CE}$ \\
\hline Sakas et al. [24] & 70/M & L4-L5 & $\mathrm{RP}, \mathrm{LBP}$ & Synovial cyst & - & - & - \\
\hline Saruhashi et al. [30] & $44 / \mathrm{F}$ & L5-S1 & $\mathrm{RP}$ & Dumbbell tumor & Iso & Hetero & Rim \\
\hline \multirow{3}{*}{$\begin{array}{l}\text { Eysel and } \\
\text { Herbsthofer [31] }\end{array}$} & $45 / \mathrm{M}$ & L3-L4 & CES & Tumor, hematoma & Нypo & - & $\operatorname{Rim}$ \\
\hline & $37 / \mathrm{F}$ & L4-L5 & $\mathrm{RP}$ & Tumor & - & - & - \\
\hline & $41 / \mathrm{M}$ & L3-L4 & LBP & Tumor & - & - & - \\
\hline \multirow[t]{2}{*}{ El Asri et al. [32] } & $42 / \mathrm{M}$ & L5-S1 & $\mathrm{RP}$ & Abscess, hematoma & - & - & - \\
\hline & $36 / \mathrm{M}$ & L5-S1 & CES & Tumor & - & - & - \\
\hline Derineck et al. [18] & $60 / \mathrm{F}$ & L1-L2 & $\mathrm{RP}$ & Epidural abscess & Iso & Hyper & $\operatorname{Rim}$ \\
\hline \multirow{7}{*}{$\begin{array}{l}\text { Carvi y Nievas and } \\
\text { Hoellerhage [17] }\end{array}$} & $83 / \mathrm{M}$ & L3-L4 & $\mathrm{RP}, \mathrm{LBP}$ & Synovial cyst & Нypo & Нypo & No \\
\hline & $45 / \mathrm{M}$ & L4-L5 & $\mathrm{RP}, \mathrm{LBP}$ & Neoplasm & Iso/hypo & Hyper & No \\
\hline & $58 / \mathrm{F}$ & $\mathrm{T} 12-\mathrm{L}^{\mathrm{a}}$ & $\mathrm{RP}$ & Meningioma & Iso/hypo & Нypo & Rim \\
\hline & $67 / \mathrm{M}$ & L4-L5 & $\mathrm{RP}, \mathrm{LBP}$ & $\begin{array}{l}\text { Synovial cyst, } \\
\text { neoplasm }\end{array}$ & Iso/hypo & Hyper & Diffuse \\
\hline & $60 / \mathrm{F}$ & L5-S1 & CES & Epidural metástasis & Iso/hypo & Hyper & Diffuse \\
\hline & $59 / \mathrm{F}$ & L2-L4 & $\mathrm{RP}$ & Hematoma & Iso/hypo & Hyper & No \\
\hline & $71 / \mathrm{F}$ & $\mathrm{L} 1-\mathrm{L} 2^{\mathrm{a}}$ & CES & Meningioma & Iso/hypo & Hyper & Diffuse \\
\hline Ekşi et al. [33] & $50 / \mathrm{M}$ & L3-L4 & LBP & Tumor & Нypo & Нypo & Rim \\
\hline Teufack et al. [34] & $73 / \mathrm{M}$ & L4-L5 & $\mathrm{RP}, \mathrm{LBP}$ & Hematoma, abscess & Hyper & Iso & Rim \\
\hline Demirc and Er [35] & $53 / \mathrm{M}$ & $\mathrm{L} 2-\mathrm{L} 3^{\mathrm{a}}$ & LBP & Tumor & Нypo & Нypo & Rim \\
\hline Akhaddar et al. [5] & $60 / \mathrm{F}$ & L2-L3 & CES & Abscess, neoplasm & Нyро & Hyper & Rim \\
\hline Gonçalves et al. [36] & $51 / \mathrm{M}$ & L2-L3 & LBP & $\begin{array}{l}\text { Hematoma, empyema, } \\
\text { NST, meningioma }\end{array}$ & Нypo & Hyper & - \\
\hline $\begin{array}{l}\text { Rahimizadeh et al. } \\
\text { [37] }\end{array}$ & $53 / \mathrm{M}$ & L3-L4 & CES & $\begin{array}{l}\text { Synovial cyst, } \\
\text { ligamentum flavum }\end{array}$ & Iso & Hetero & - \\
\hline Yoo et al. [38] & $32 / \mathrm{M}$ & L2-L3 & LBP RP & Synovial cyst & - & Hyper & - \\
\hline Park [39] & $43 / \mathrm{M}$ & $\mathrm{L} 2-\mathrm{L} 3^{\mathrm{a}}$ & $\mathrm{RP}, \mathrm{LBP}$ & $\begin{array}{l}\text { Multiple } \\
\text { Schwannomas }\end{array}$ & - & - & Rim \\
\hline Ajayi [40] & $65 / \mathrm{F}$ & L4-L5 & $\mathrm{RP}, \mathrm{LBP}$ & $\begin{array}{l}\text { NST, meningioma, } \\
\text { abscess }\end{array}$ & Нypo & Hyper & Rim \\
\hline Li et al. [11] & $48 / \mathrm{M}$ & L5-S1 & LBP & Tumor & Iso & Iso & $\operatorname{Rim}$ \\
\hline Diyora et al. [41] & $44 / \mathrm{M}$ & L4-L5 & CES & Tumor, arachnoiditis & Iso & Hyper & Rim \\
\hline \multirow[t]{5}{*}{ Zarrabian et al. [27] } & $48 / \mathrm{M}$ & L4-L5 & LBP, RP & Epidural abscess & Iso & Hyper & Rim \\
\hline & $77 / \mathrm{M}$ & L3-L4 & LBP, RP & Epidural hematoma & Iso & Hyper & - \\
\hline & $69 / \mathrm{M}$ & L2-L3 & LBP, RP & Synovial cyst & Iso & Hyper & - \\
\hline & $61 / \mathrm{M}$ & L3-L4 & LBP & Epidural hematoma & Iso & Нypo & - \\
\hline & $60 / \mathrm{M}$ & L4-L5 & $\mathrm{RP}$ & Epidural abscess & Iso & Нypo & Rim \\
\hline Kil et al. [42] & $57 / \mathrm{M}$ & L2-L3 & LBP & Hematoma, neoplasm. & Iso & Hyper & - \\
\hline Takano et al. [43] & 78/M & L3-L4 & LBP & $\begin{array}{l}\text { Neoplasm, hematoma, } \\
\text { abscess }\end{array}$ & Нypo & Iso & Rim \\
\hline \multirow[t]{2}{*}{ Present study } & $45 / \mathrm{M}$ & L4-L5 & CES & Pseudotumor & Iso & Hyper & Rim \\
\hline & $64 / \mathrm{M}$ & $\mathrm{L} 3-\mathrm{L} 4^{\mathrm{a}}$ & $\mathrm{RP}, \mathrm{LBP}$ & Meningioma, NST & Iso & Нyро & Rim \\
\hline
\end{tabular}

LBP low back pain, $R P$ radicular pain, $C E S$ cauda equina syndrome, NST nerve sheath tumor, T1WI T1 weighted image, $T 2 W I$ T2 weighted image, $C E$ contrast enhancement, - not reported, Hetero heterogeneous, Hypo hypointense, Hyper hyperintense, Iso isointensive

${ }^{a}$ Intradural cases among nerve roots, thecal sac and intervertebral discs, that may facilitate sequestered fragment shifts to the posterior epidural space $[6,14]$. However, dense adhesions of ventral dura mater to posterior longitudinal ligament congenitally formed or caused by some local inflammatory processes turn difficult lateral migration of disc fragments, facilitating penetration into ventral dura mater, usually thinner than dorsal one. Other predisposing anatomic factors to intradural migration as congenital narrowing of the spinal canal, fineness of the dura mater and previous surgeries have been 
described in the literature as well $[15,16]$. It should be noted that in our intradural case the fragment was attached to a thin dorsal dura and no ventral tear was found. We speculated that the fragment first migrated to the posterior epidural space and then tore the dorsal surface of the dura to penetrate inside it. No previous surgery/spinal trauma or narrow spinal canal appeared in this case. Patients with posterolateral intradural sequestered discs without predisposing conditions had been reported before [17].

\section{Clinical presentation}

There are no specific clinical features that could distinguish patients with atypical disc herniations from those with tumors. Clinical presentation may be similar to anterior epidural lumbar disc herniations whose typical symptoms include low back pain and radiculopathy. However, there is a higher incidence of cauda equine syndrome (CES) in posterior sequestered lumbar disc herniations [5, 18]. Our review shows about $30 \%$ of cases suffered CES and $54 \%$ of them radicular pain, being the most common symptom (Table 1) probably due to the more frequent posterolateral fragment position.

\section{Diagnostic imaging}

MRI is the standard imaging method for evaluating spinal pathologies. Migrated disc fragments usually appear hyperintense in $80 \%$ of cases on T2-weighted images, and hypointense on T1-weighted images, as compared with the disc origin $[6,19,20]$. Rim enhancement after gadolinium injection is usually shown around the extruded fragment and is related to the presence of inflammatory response and neovascularization [21-23]. Although these findings are present in most of cases, only in a few of them MRI alone would allow to determine the exact diagnosis, especially when there are associated changes in the disc space and adjacent endplates. Common misdiagnosis of these posteriorly migrated discs derive from their low incidence compared to the other more usual spinal lesions presenting with a similar radiological appearance [18, 24-27]. Hematomas, abscesses and synovial cysts followed by neoplasms like schwannoma and mengioma are the specific lesions most frequently misdiagnosis with posterior sequestrated disc herniation (Table 1).

We only obtained one definite radiological diagnosis of posterolateral epidural fragment disc in a case with typical radiological characteristics and previous history of lumbar discopathy.

\section{Treatment}

Early surgical treatment has been proposed as the management of choice to prevent further severe neurological deficits $[5,14,28]$. Several case reports and series support it reporting the most common patient's complete recovery without complications after surgery. However, a more recent study describes a case series of patients with posterior epidural lumbar disk herniation treated successfully with conservative therapy showing spontaneous regression of herniated disk with relief of symptoms [29]. One of our patients was first managed conservatively without new neurological deficit. The other two patients underwent early surgery due to neurological symptoms with severe radicular compression, and showed full recovery on follow-up after surgery, which may imply the superiority of the early surgical treatment in this set of patients.

\section{Conclusions}

Low incidence and absence of characteristic clinical and radiological features make diagnosis of posteriorly sequestered lumbar disk migration utterly difficult. Synovial cysts, hematomas and abscesses are the most frequent lesions which should be considered to make a differential diagnosis. Initial conservative treatment may be an option in cases of minimal neurological deficit and appropriate pain control, while the early surgical treatment is the most common recommendation to optimize results.

\section{Compliance with ethical standards}

Conflict of interest The authors declare that they have no conflict of interest.

\section{References}

1. Lombardi V. Lumbar spinal block by posterior rotation of anulus fibrosus. Case Report J Neurosurg. 1973;39:642-7. https://doi. org/10.3171/jns.1973.39.5.0642

2. DANDY WE. Serious complications of ruptured intervertebral disks. J Am Med Assoc. 1942;119:474-7.

3. Brock M, Patt S, Mayer HM. The form and structure of the extruded disc. Spine. 1992;17:1457-61.

4. Epstein NE, Syrquin MS, Epstein JA, Decker RE. Intradural disc herniations in the cervical, thoracic, and lumbar spine: report of three cases and review of the literature. J Spinal Disord. 1990;3:396-403.

5. Akhaddar A, El-Asri A, Boucetta M. Posterior epidural migration of a lumbar disc fragment: a series of 6 cases. J Neurosurg Spine. 2011;15:117-28. https://doi.org/10.3171/2011.3.SPINE10832

6. Schellinger D, Manz HJ, Vidic B, Patronas NJ, Deveikis JP, Muraki AS, Abdullah DC. Disk fragment migration. Radiology. 1990;175:831-6. https://doi.org/10.1148/radiology.175.3.2343133

7. Wiltse LL, Fonseca AS, Amster J, Dimartino P, Ravessoud FA. Relationship of the dura, Hofmann's ligaments, Batson's plexus, and a fibrovascular membrane lying on the posterior surface of the vertebral bodies and attaching to the deep layer of the posterior longitudinal ligament. An anatomical, radiologic, and clinical study. Spine. 1993;18:1030-43. 
8. Hogan QH. Lumbar epidural anatomy. A new look by cryomicrotome section. Anesthesiology. 1991;75:767-75.

9. Fick R (2012) Handbuch der anatomie und mechanik der gelenke. Рипол Классик

10. Mut M, Berker M, Palaoglu S. Intraradicular disc herniations in the lumbar spine and a new classification of intradural disc herniations. Spinal Cord. 2001;39:545-8. https://doi.org/10.1038/sj. sc.3101204

11. Li K, Li Z, Geng W, Wang C, Ma J. Postdural disc herniation at L5/S1 level mimicking an extradural spinal tumor. Eur Spine J. 2016;25(Suppl 1):80-3. https://doi.org/10.1007/s00586-0154125-5

12. Sengoz A, Kotil K, Tasdemiroglu E. Posterior epidural migration of herniated lumbar disc fragment. J Neurosurg Spine. 2011;14:313-7. https://doi.org/10.3171/2010.11.SPINE10142

13. Dosoglu M, Is M, Gezen F, Ziyal MI. Posterior epidural migration of a lumbar disc fragment causing cauda equina syndrome: case report and review of the relevant literature. Eur Spine J. 2001;10:348-51.

14. Kuzeyli K, Cakir E, Usul H, Baykal S, Yazar U, Karaarslan G, Arslan E, Peksoylu B. Posterior epidural migration of lumbar disc fragments: report of three cases. Spine. 2003;28:E64-7. https:// doi.org/10.1097/01.BRS.0000042272.17850.49

15. Prestar FJ, Schattke HH. Intradural lumbar disc herniations: report of three cases. Minim Invasive Neurosurg. 1995;38:125-8. https:// doi.org/10.1055/s-2008-1053471

16. Spencer DL, Irwin GS, Miller JA. Anatomy and significance of fixation of the lumbosacral nerve roots in sciatica. Spine. 1983;8:672-9.

17. Carvi y Nievas MN, Hoellerhage HG. Unusual sequestered disc fragments simulating spinal tumors and other space-occupying lesions. Clinical article. J Neurosurgery Spine. 2009;11:42-8. https://doi.org/10.3171/2009.3.SPINE08161.

18. Derincek A, Ozalay M, Sen O, Pourbagher A. Posterior epidural mass: can a posteriorly migrated lumbar disc fragment mimic tumour, haematoma or abscess? Acta Orthop Belg. 2009;75:423-7.

19. Chen CY, Chuang YL, Yao MS, Chiu WT, Chen CL, Chan WP. Posterior epidural migration of a sequestrated lumbar disk fragment: MR imaging findings. Am J Neuroradiol. 2006;27:1592-4.

20. Masaryk TJ, Ross JS, Modic MT, Boumphrey F, Bohlman H, Wilber G. High-resolution MR imaging of sequestered lumbar intervertebral disks. Am J Roentgenol. 1988;150:1155-62. https:// doi.org/10.2214/ajr.150.5.1155

21. Wasserstrom R, Mamourian AC, Black JF, Lehman RA. Intradural lumbar disk fragment with ring enhancement on MR. Am J Neuroradiol. 1993;14:401-4.

22. Olmarker K, Blomquist J, Stromberg J, Nannmark U, Thomsen P, Rydevik B. Inflammatogenic properties of nucleus pulposus. Spine. 1995;20:665-9.

23. Lakshmanan P, Ahuja S, Lyons K, Howes J, Davies PR. Sequestrated lumbar intervertebral disc in the posterior epidural space: a report on two cases and review of the literature. Spine J. 2006;6:583-6. https://doi.org/10.1016/j.spinee.2005.09.009

24. Sakas DE, Farrell MA, Young S, Toland J. Posterior thecal lumbar disc herniation mimicking synovial cyst. Neuroradiology. 1995;37:192-4.

25. Watanabe N, Ogura T, Kimori K, Hase H, Hirasawa Y. Epidural hematoma of the lumbar spine, simulating extruded lumbar disk herniation: clinical, discographic, and enhanced magnetic resonance imaging features. A case report. Spine. 1997;22:105-9.

26. Bonaroti EA, Welch WC. Posterior epidural migration of an extruded lumbar disc fragment causing cauda equina syndrome. Clin Magn Reson Imaging Eval Spine. 1998;23:378-81.
27. Zarrabian MM, Diehn FE, Kotsenas AL, Wald JT, Yu E, Nassr A. Dorsal Lumbar Disc Migrations with Lateral and Ventral Epidural Extension on Axial MRI: A Case Series and Review of the Literature. Am J Neuroradiol. 2016. https://doi.org/10.3174/ajnr. A4875.

28. Turan Y, Yilmaz T, Gocmez C, Ozevren H, Kemaloglu S, Teke M, Sariyildiz MA, Ceviz A, Temiz C. Posterior epidural migration of a sequestered lumbar intervertebral disc fragment. Turk Neurosurg. 2017;27:85-94. https://doi.org/10.5137/1019-5149.JTN. $14712-15.1$

29. Tarukado K, Ikuta K, Fukutoku Y, Tono O, Doi T. Spontaneous regression of posterior epidural migrated lumbar disc fragments: case series. Spine J. 2015;15:e57-62. https://doi.org/10.1016/j. spinee.2013.07.430

30. Saruhashi Y, Omura K, Miyamoto K, Katsuura A, Hukuda S. A migrated lumbar disc herniation simulating a dumbbell tumor. J Spinal Disord. 1999;12:307-9.

31. Eysel P, Herbsthofer B. Dorsal compression of the epidural cord due to free sequestral lumbar prolapse. Diagnostic problems in magnetic resonance imaging and computed tomography. Arch Orthop Trauma Surg. 2001;121:238-40.

32. El Asri AC, Naama O, Akhaddar A, Gazzaz M, Belhachmi A, El Mostarchid B, Boucetta M. Posterior epidural migration of lumbar disk fragments: report of two cases and review of the literature. Surg Neurol. 2008;70:668-671. https://doi.org/10.1016/j.surneu. 2007.06.034. discussion 671

33. Ekşi M, Yener U, Akakin A, Akakin D, Konya D. Posterior epidural disc herniation at L3-L4 mimicking a spinal tumor: a case report. J Neurosurg Sci. 2010;54:71-76.

34. Teufack SG, Singh H, Harrop J, Ratliff J. Dorsal epidural intervertebral disk herniation with atypical radiographic findings: case report and literature review. J Spinal Cord Med. 2010;33:268-71.

35. Demirci A, Er U. A lumbar disc herniation mimicking spinal tumor with intra- and extradural components. Spine J. 2011;11:90-91. https://doi.org/10.1016/j.spinee.2010.10.015

36. Gonçalves FG, Hanagandi PB, Torres CI, DelCarpio-O’Donovan R. Posterior migration of lumbar disc herniation-imaging dilemma due to contrast contraindication: a case report. Radiol Bras. 2012;45:170-2.

37. Rahimizadeh A, Soufiani H, Rahimizadeh A. Posterior epidural migration of sequestered lumbar disc fragment causing cauda equina syndrome. Coluna/Column. 2013;12:78-80.

38. Yoo YS, Ju CI, Kim SW, Kim DM. Posterior epidural migration of an extruded lumbar disc mimicking a facet cyst: a case report. Korean J Spine. 2015;12:12-4. https://doi.org/10.14245/kjs.2015. 12.1.12

39. Park Y-S, Hyun S-J, Kim K-J, Jahng T-A. Multiple intradural disc herniations masquerading as intradural extramedullary tumors: a case report and review of the literature. Korean J Spine. 2016;13:30-32.

40. Ajayi O, Shoakazemi A, Tubbs RS, Moisi M, Rostad S, Newell DW. Atypical presentation of a sequestered posterolateral disc fragment. Cureus. 2016;8:e502 https://doi.org/10.7759/cureus.502

41. Damjibhai Diyora B, Giri S, Giri D, Kotecha N, Patil S. An unusual case of dorsally sequestrated disk mimicking tumor with cauda equina syndrome. J Spinal Surgery. 2016;3:15.

42. Kil JS, Park JT. Posterior epidural herniation of a lumbar disk fragment at L2-3 that mimicked an epidural hematoma. Korean J Spine. 2017;14:115-7. https://doi.org/10.14245/kjs.2017.14.3.115

43. Takano M, Hikata T, Nishimura S, Kamata M. Discography aids definitive diagnosis of posterior epidural migration of lumbar disc fragments: case report and literature review. BMC Musculoskelet Disord. 2017;18:151 https://doi.org/10.1186/s12891-017-1516-2 